Historic, Archive Document

Do not assume content reflects current scientific knowledge, policies, or practices. 



\section{copet \\ USDA Forest Service}

Research Paper RM-93

July 1972

Rocky Mountain Forest and Range Experiment Station

Forest Service

U.S. Department of Agriculture

Fort Collins, Colorado

\section{MORPHOMETRY OF THREE SMALL WATERSHEDS, BLACK HILLS, SOUTH DAKOTA, AND SOME HYDROLOGIC IMPLICATIONS}

by Teruo Yamamoto and Howard K. Orr

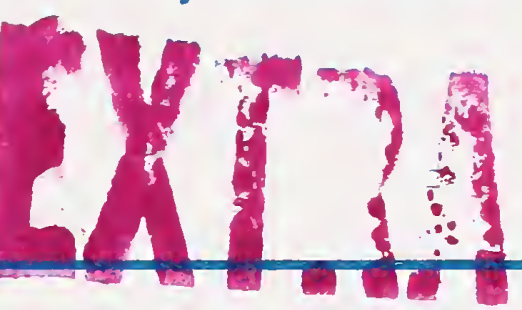

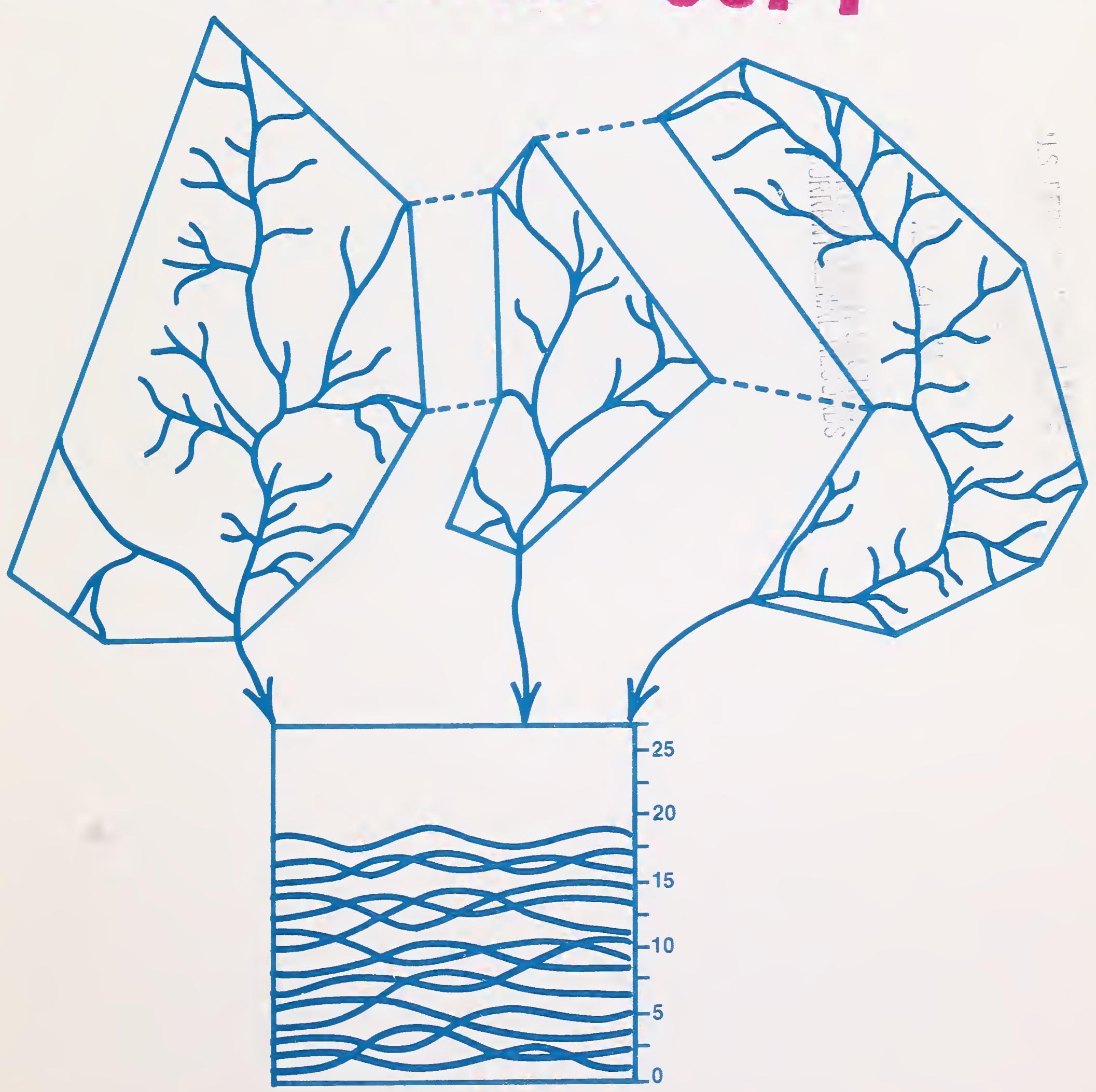




\begin{abstract}
Morphometry and hydrologic character of three small contiguous watersheds are analyzed in terms of elementary length dimensions, nondimensional expressions, and similitude concepts. The approach is based on theory that watershed morphology which evolves under the influence of dynamic processes should be consistently related to quantitative resultants of the processes. Within this framework, maximum length of master watershed and the average relief of first order basins scale most nearly the same as volume yield and stormflow peaks. It is theorized, therefore, that these form elements (1) exert primary control over or are closely related to volume yield and peak flows, and (2) are better indicators of relative volume yields and peak flows than is area on the surface of the laccolith. Different morphometric characteristics, however, may be controlling elements under conditions of different parent rock and climate. Dimensionless parameters such as shape are also examined.
\end{abstract}

Keywords: Hydrology, morphology, water yield. 


\title{
Morphometry of Three Small Watersheds, Black Hills, South Dakota, and Some Hydrologic Implications
}

\author{
by \\ Teruo Yamamoto, Associate Geologist, and Howard K. Orr, Hydrologist \\ Rocky Mountain Forest and Range Experiment Station '
}

'Authors are assigned to the Station's field unit at Rapid City, in cooperation with South Dakota School of Mines and Technology; central headquarters is maintained at Fort Collins, in cooperation with Colorado State University. 


\section{Contents}

Page

The Study Watersheds ... . . . . . . . . . . . 1

Concepts and Methods . . . . . . . . . . . . . . . 3

Morphometric Measurement ............. 3

Dimensional Analysis and Geometric Similarity. . . . . . 3

Concepts ....................... 3

Analytical Procedures .............. 4

Results .......................... . . . 4

Watershed Areas and Yields ............ 4

Linear Aspects of Drainage Basin and Channel System. . . 6

Dimensional Elements . . . . . . . . . . . 6

Dimensionless Elements . . . . . . . . . . . 6

Basin Azimuth. . . . . . . . . . . . . 7

Area Aspects of Drainage Basins ......... 7

Dimensional Elements . . . . . . . . . . . . 7

Dimensionless Elements (Shape). . . . . . . . . 8

Relief Aspects of Drainage Basins .......... 8 8

Dimensional . . . . . . . . . . . . . . . 8

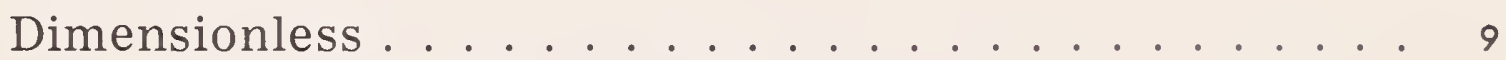

Hypsometric Function. . . . . . . . . . . . 10

Longitudinal Profiles of Principal Channel........ וו

Discussion-Summary . . . . . . . . . . . . . . 11

Literature Cited. . . . . . . . . . . . . . . . 12

Definitions and Derivations .................. 14 


\title{
Morphometry of Three Small Watersheds, Black Hills, South Dakota,
}

\author{
and Some Hydrologic Implications
}

\author{
Teruo Yamamoto and Howard K. Orr
}

\begin{abstract}
Every watershed is unique. Its "uniqueness" may not be clearly evident, even to the practiced observer, but it in some way accounts for or is related to measurable differences in hydrologic behavior of contiguous and otherwise macroscopically similar watersheds. Morphometric (form) properties, for example, comprise a class of physical factors acknowledged as important in hydrologic behavior but which are often difficult to apprehend, measure, express, or evaluate. Much of the qualitative historical effort in this field has been on a regional basis and has concentrated on evolution of landforms. However, quantitative methods are by now so well established and accepted as to stimulate sporadic efforts to relate morphometric properties to hydrologic performance.

Such relationships have not been studied intensively on small forested watersheds. The present study was undertaken in an initial attempt to identify significant morphometric parameters or classes of parameters and their flow implications. This kind of information is sought not only as a means of improving our understanding of basin morphology, water yield, and possible forest treatment response, but also to establish a geomorphic benchmark upon which to build further study and better understanding of the hydrologic functioning of small forested watersheds in other geologic types in the Black Hills.
\end{abstract}

\section{The Study Watersheds}

Three adjoining watersheds, 217, 89, and 190 acres, referred to as the Sturgis watershed, are being studied in detail. They are headwater tributaries of Alkali Creek, which drains a portion of the Vanocker Laccolith in the northeastern Black Hills near Sturgis, South Dakota (fig. 1). A number of such laccoliths, all of Tertiary origin, are exposed at scattered locations across the northern Black Hills.

The watersheds, numbered 1, 2, and 3 from east to west, all drain in a generally northerly direction (fig. 2). The watershed surfaces have been deeply dissected, apparently by the con- centration of erosion along primary lines of weakness that developed during cooling of the igneous mass, and fractures that developed along these lines during subsequent erosional unloading.

The parent rock is a hornblende-biotite quartz latite porphyry. ${ }^{2}$ It is granitelike, dense, structurally firm, and practically impervious except in fracture and crushed zones. The most prominent and important feature of the basic rock structure is shallow sheeting, a form of rupture or cracking, parallel to the topographic surface. Sheeting decreases with increasing depth, where vertical jointing becomes a common feature.

Two distinctive kinds of soil are present in the watersheds - Gray Wooded soil and lithosol. The lithosols are shallow, lack B horizons or other clearly developed horizons, and consist of a weathered mass of hard rock or hard rock fragments and intermixed soil. These occupy approximately 47 percent of the total study area. The Gray Wooded soils (approximately 41 percent of total area) as described by Nishimura and Willmot ${ }^{3}$ compare with published morphology (Radeke and Westin 1963). The most distinctive characteristics (from which the name is derived) is a well-developed A horizon of gray, very friable loam ranging from about 10 to 30 inches thick. The gray horizon grades into a brown $\mathrm{B}^{2}$ horizon about 3 to 16 inches thick, ranging from clay to sandy-loam texture and granular to subangular blocky structure. This B horizon commonly terminates rather abruptly on the parent rock. Scattered areas of rock outcrop and rock slides occupy approximately 12 percent of the total area of all three watersheds.

All three watersheds are dominated by ponderosa pine forest. Because of many years of protection as a municipal water supply source,

${ }^{2}$ Identified in detailed petrographic analysis of drill cores in 1969 by Professor Edward Bingler, formerly of the Geology Department, South Dakota School of Mines and Technology, Rapid City.

${ }^{3}$ Veteran Lookout Soils Report to Forest Supervisor, Black Hills National Forest, from Robert Gardner, Assistant Regional Forester, R-2 January 17, 1963, described by J. Nishimura and R. Willmot. 

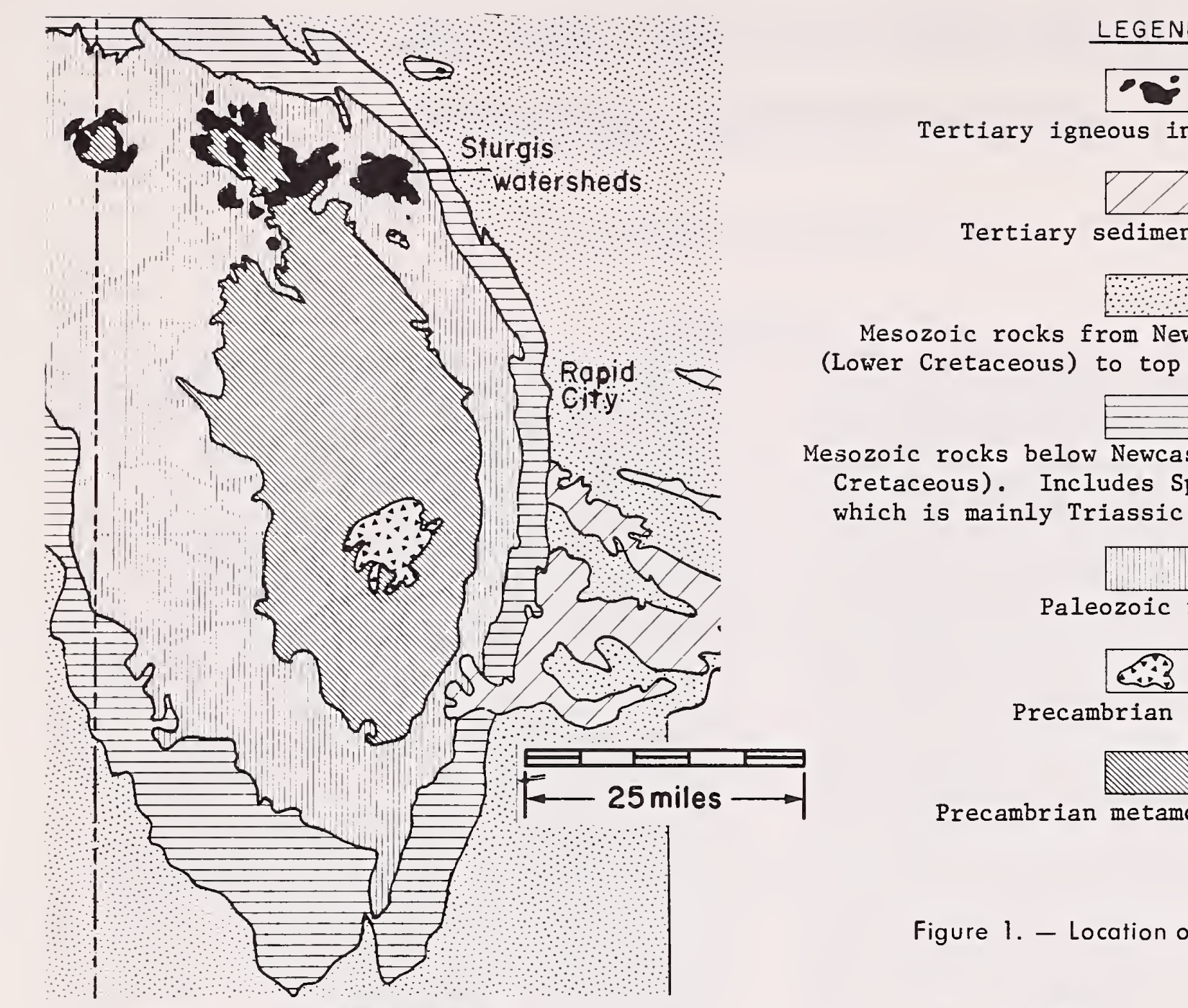

Tertiary igneous intrusive rocks

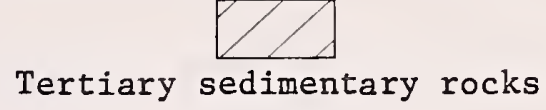

Mesozoic rocks from Newcastle Sandstone (Lower Cretaceous) to top of Upper Cretaceous

Mesozoic rocks below Newcastle sandstone (Lower Cretaceous). Includes Spearfish Formation, which is mainly Triassic but partly Permian.

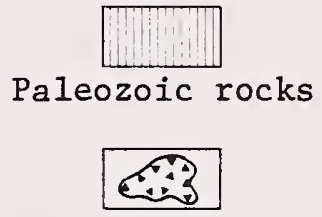

Precambrian granite

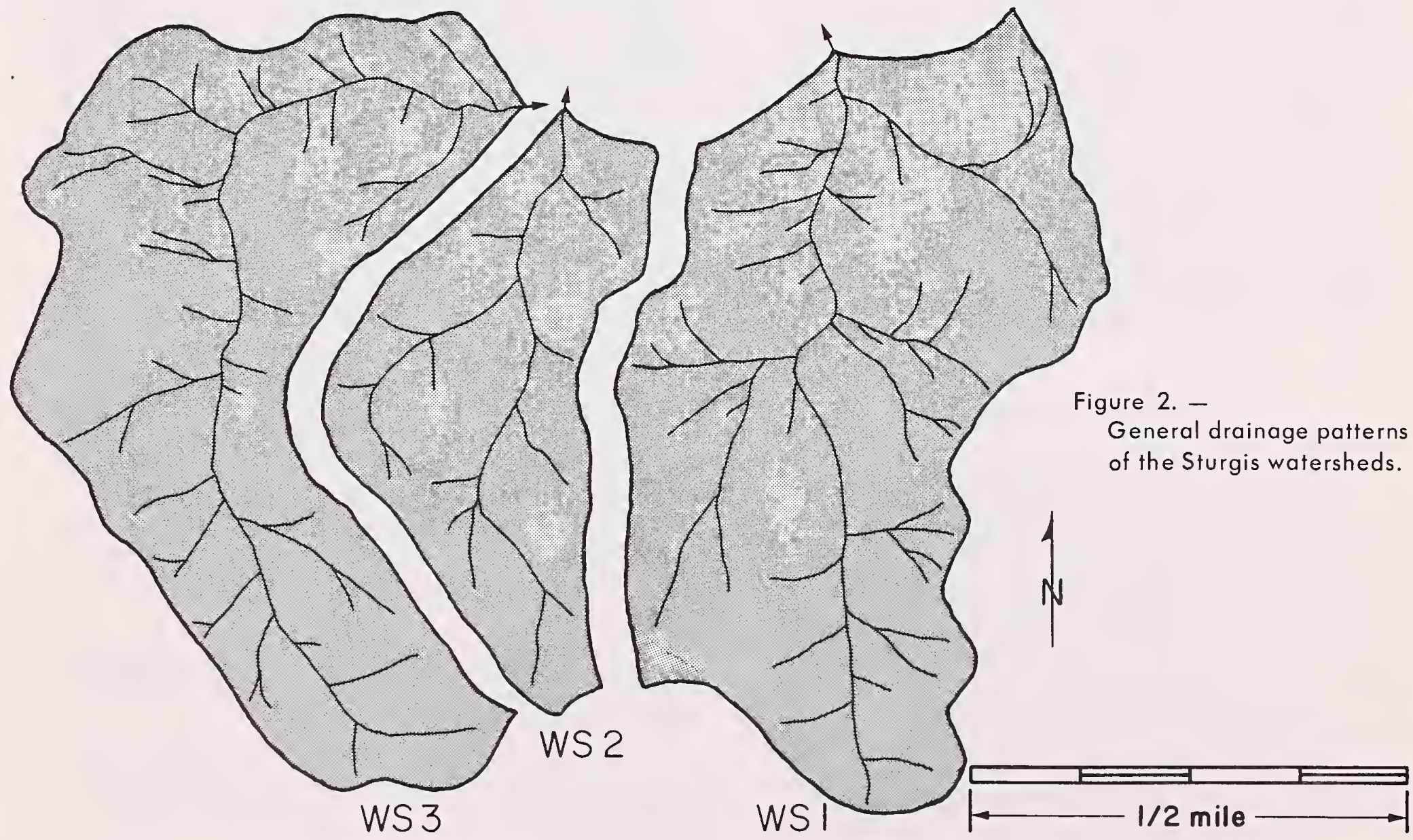

Figure 1. - Location of the Sturgis watersheds.

Precambrian metamorphic rocks

General drainage patterns of the Sturgis watersheds. 
there is a greater than average amount of mature to overmature and decadent sawtimber. However, second-growth pine (seedling-sapling to pole size) is present on 60 to 85 percent of total area in different watersheds. A scattering of white spruce, birch, aspen, and several deciduous shrub species occur mainly along channels. A variety of forbs and grasses are present, but production is relatively low over much of the area due, at least in part, to the relatively dense forest canopy.

Runoff to the drainage channels is primarily subsurface through the shallow and highly porous mantle. Infiltration capacity is seldom exceeded by local rainfall intensities. Little evidence of overland runoff is visible. Ground water levels and streamflow stages respond quickly to spring and early summer precipitation and recede rapidly to low base flow levels.

Streamflow is continuously recorded at the mouth of each watershed and precipitation is measured in a network of seven gages in the three watersheds combined. Annual precipitation has averaged 29.5 inches on all three watersheds through water year 1968 .

\section{Concepts and Methods}

Horton (1945) proposed the theory that drainage basins develop in an orderly manner according to certain "laws" of drainage composition. These laws are expressed quantitatively by relating the proportionality of number of streams, stream lengths, and slopes to "stream order' (see section on Definitions and Derivations). Morphometry of the three Sturgis watersheds is interpreted on the basis of the steady state theory advocated by Strahler (1964) and Hack (1960), an extension of Horton's theory. According to this theory, steady state is reached by continual adjustment of input (mainly precipitation) and output (flow and debris) until a characteristic topographic form develops which is quasi-time-independent. Continual readjustment of surface geometry must occur as the relief lowers, but takes place at an imperceptibly slow rate, barring catastrophic events.

Scheidegger and Langbein (1966) present further logical elaboration of this theory, according to which an "ensemble" (which could be a group of watersheds on a single parent rock type) contains samples of the changes that occur on a single watershed in time. It follows, then, that variation in space can be substituted for variation in time, and the rationale for detailed comparison of individual watersheds in the following analyses is established. Dif- ferences between watersheds are then interpreted as more likely real than due to sampling or measurement error. These principles lead to a corollary theory that watershed form elements which evolve under the influence of dynamic processes should be consistently related to quantitative resultants of the processes.

The common expression of water yields and peaks (both are resultants of dynamic processes) on a per unit area basis (inches or acre-feet per square mile for yield and cubic feet per second per square mile (CSM) for peaks, as examples) is tacit admission of gross area control of output. It may at the same time be taken as indirect assertion that, input factors being the same, output should be strictly proportional to area. This is seldom the case, however. In a humid climate, for example, unit area yields tend to increase with area of small watersheds (Ogrosky and Mockus 1964). This observation is in agreement, at least directionally, with similitude concepts, which suggest that unit area depth of yield must increase in the same proportion as increase in square root of total watershed area.

\section{Morphometric Measurement}

A 1:24,000 U.S. Geological Survey Topographic map was enlarged to a scale of $1: 3,600$ for morphometric measurements. Streams were then systematically assigned to "orders." The smallest unbranched tributaries were designated first order, second order channel segments are formed by the union of two first order channel segments, and so forth, for successively higher orders (Strahler 1952). Form elements of the drainage net were then systematically measured with chartometer and planimeter; questionable interpretations were field checked and corrected as necessary. Three main groups of elements measured were: (1) length aspects of the watershed and the channel system, such as stream lengths, watershed perimeters, and watershed lengths; (2) area aspects of watersheds including basin areas, basin shapes, drainage density, and channel frequency; and (3) relief aspects of the surface such as channel gradient, ground slope, relief, and longitudinal profile. These elements are derived mainly from Horton's (1945) pioneering work and from the later contributions of Strahler $(1958,1964)$ and his colleagues.

\section{Dimensional Analysis and Geometric Similarity}

Concepts. - Dimensional expression and the application of simple principles of geometric similarity provide a useful means of analyzing 
and comparing form and mechanical aspects of drainage basins not to be found in probability statistics - particularly when the number of sampled watersheds is small.

In the present case, three small contiguous watersheds are studied and compared in detail. For the most part, data are considered as whole-population statistics, subject only to measurement error. In this context, both the concept and application of morphometric analysis differs somewhat from the more usual approach which involves statistical inference.

Two watersheds are said to be geometrically similar when all corresponding linear elements of the two watersheds are in the same scale ratio (the same proportions) and when all corresponding angles and other dimensionless elements of the two systems have identical values (Strahler 1964). Scale ratios derived from average values have ordinarily been used in regional analyses. This approach has not apparently posed serious difficulties on such large scale because (1) a large enough number of watersheds are ordinarily included to minimize change of bias due to heterogeneous variances, and (2) master watersheds are within a narrow enough size range to mitigate the effect of size differences on scale comparisons of within-watershed elements. However, in our more restricted situation - small number and relatively small area of watersheds on a single geologic type - use of averages may have a different connotation. For example, in a strict prototype/scale model situation, the dimensions of first order basins in the larger prototype watershed should be proportionately larger than the corresponding dimensions of first order basins in a smaller, model watershed. In the real world, at least on the small scale we are presently considering, this is not a sound assumption. For example, on the same lithology under the same climate, the average of first order basin areas in similarly oriented watersheds would be expected to be about the same regardless of the size or order of the "master" or highest order watershed. (The same principle could apply also to higher orders.) On this basis it is theorized that sum total of first order basin areas may be as meaningful or more meaningful morphologically and hydrologically than average area.

Analytical Procedures. - All measured geometric elements (length, area, and volume) were reduced to root length dimensions (L) and dimensionless numbers (angles and ratios). Linear scale ratios ${ }^{4}$ (conceptually the same as

\footnotetext{
specified.
}

map scale) were calculated and used to compare dimensions by size. That is, if two basins are geometrically similar, corresponding length dimensions will all be in the same proportion - in other words, measures of corresponding dimensions of length (L), reciprocal of the inverse of length $\left(\mathrm{L}^{-1}\right)$, square root of length squared $\left(\mathrm{L}^{2}=\right.$ area $)$, and cube root of length cubed $\left(\mathrm{L}^{3}=\right.$ volume $)$ will all have the same ratio. Dimensionless numbers are used to compare form independent of size. Furthermore, dimensionless properties such as angles and slope gradients of corresponding parts will be equal. In nature, identical form values obviously cannot be expected, but close approximations, if existent, will be evident.

In analyzing hydrologic implications, it was theorized that those morphometric elements which scale most nearly the same as volume of annual water yield, for example, should be primary controls of or related to volume yield. The study watersheds have all received practically the same "depths" of precipitation input each year. This is the entry point to systems in which component elements influence the distribution or routing of input, and consequently control or influence the volume output in some way. In this process we have assumed that basin characteristics other than geometry are essentially similar, or are themselves related to geometry in some consistent and logical manner. Subsequent analyses will be aimed at identification and explanation of significant interactions which could involve a variety of other factors including input (precipitation and other external atmospheric variables), forest and other plant cover, and soil and bedrock.

Throughout the following discussion, scale ratios are presented as WS1/WS2, WS3/WS2, and WS1/WS3 (WS = watershed), in line with the previously stated large area/small area (prototype/model) specification.

\section{Results}

\section{Watershed Areas and Yields}

The study watersheds differ (are unique), first of all, in terms of gross area (table 1). Total annual water yields (volume), as expected, rank in the same order.

In comparing WS $1 / \mathrm{WS} 3$, scale ratios of the yields are very nearly the same as scale ratios of areas of both the average and sum totals of first order basins and also master orders (table 2 ), and are consistent year to year. However, in the two other comparisons, (WS1/WS2 and WS3/WS2), the scale ratios of gross volume yield are smaller than the scale ratios of the 
Table 1.--Annual precipitation and water yield, Sturgis watershed

\begin{tabular}{|c|c|c|c|c|c|c|c|c|c|}
\hline \multirow{3}{*}{$\begin{array}{l}\text { Water } \\
\text { year }\end{array}$} & WS1 & \multicolumn{2}{|c|}{ (217 acres) } & WS 2 & \multicolumn{2}{|c|}{ (89 acres) } & WS 3 & \multicolumn{2}{|c|}{ (190 acres) } \\
\hline & $\begin{array}{l}\text { Precipi- } \\
\text { tation }\end{array}$ & \multicolumn{2}{|c|}{ Yield } & $\begin{array}{l}\text { Precipi- } \\
\text { tation } \\
\end{array}$ & \multicolumn{2}{|c|}{ Yield } & $\begin{array}{l}\text { Precipi- } \\
\text { tation }\end{array}$ & \multicolumn{2}{|c|}{ Yield } \\
\hline & Inches & $\begin{array}{l}\text { Acre- } \\
\text { feet }\end{array}$ & Inches & Inches & $\begin{array}{l}\text { Acre- } \\
\text { feet }\end{array}$ & Inches & Inches & $\begin{array}{l}\text { Acre- } \\
\text { feet }\end{array}$ & Inches \\
\hline 1964 & 31.5 & 118.08 & 6.54 & 32.4 & 53.47 & 7.21 & 31.8 & 100.07 & 6.26 \\
\hline 1965 & 34.8 & 232.37 & 12.85 & 34.3 & 100.35 & 13.53 & 34.7 & 189.05 & 11.88 \\
\hline 1966 & 24.8 & 69.44 & 3.84 & 24.0 & 29.82 & 4.02 & 24.4 & 52.57 & 3.32 \\
\hline 1967 & 32.4 & 258.23 & 14.28 & 31.8 & 107.77 & 14.53 & 32.3 & 195.70 & 12.36 \\
\hline 1968 & 24.5 & 35.26 & 1.95 & 24.1 & 17.06 & 2.31 & 24.6 & 28.18 & 1.78 \\
\hline Average & 29.60 & ${ }^{1} 142.68$ & 7.89 & 29.32 & ${ }^{1} 61.70$ & 8.32 & 29.56 & 113.11 & 7.12 \\
\hline
\end{tabular}

1 Used in illustration of scale ratio in footnote 2 , table 2.

Table 2.--Watershed areas (horizontal projection), and scale ratios ( $\lambda$ ) of watershed areas, water yields, and stormflow peaks (average of 21 events), water years 1964-68

\begin{tabular}{|c|c|c|c|c|c|c|c|c|}
\hline \multirow{3}{*}{ Watersheds } & \multicolumn{2}{|c|}{ Area } & \multicolumn{6}{|c|}{ Scale ratios, $\lambda$} \\
\hline & \multirow[b]{2}{*}{$\begin{array}{c}\text { First order } \\
\text { average }\end{array}$} & \multirow[b]{2}{*}{$\begin{array}{r}\text { Master } \\
\text { order } \\
\end{array}$} & \multirow[b]{2}{*}{ Watersheds } & \multicolumn{3}{|c|}{ Area } & \multirow{2}{*}{$\begin{array}{r}\text { Average } \\
\text { yield } \\
\end{array}$} & \multirow{2}{*}{$\begin{array}{l}\text { Peak } \\
\text { flow }^{3}\end{array}$} \\
\hline & & & & $\begin{array}{c}\text { First order } \\
\text { average }\end{array}$ & $\begin{array}{c}\text { First order } \\
\text { total }\end{array}$ & $\begin{array}{r}\text { Master } \\
\text { order } \\
\end{array}$ & & \\
\hline & --- Acr & -- & & & & & & \\
\hline WS 1 & 2.84 & 217 & WS $1 /$ WS 2 & 1.01 & 1.69 & 1.56 & 1.31 & 1.29 \\
\hline WS2 & 2.80 & 89 & WS $3 /$ WS 2 & .97 & 1.63 & 1.46 & 1.22 & 1.28 \\
\hline WS 3 & 2.71 & 190 & WS $1 /$ WS 3 & 1.05 & 1.04 & 1.07 & 1.08 & 1.01 \\
\hline
\end{tabular}

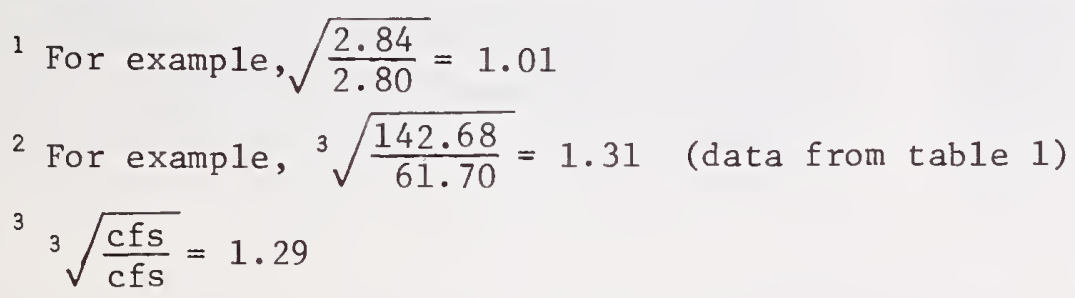

total areas of first order basins and areas of the master orders (total watershed). In other words, WS1 and WS3 both yield somewhat less water for their size than WS2. Order one average areas are so nearly the same (near 1:1 scale) in all three comparisons that it does not appear they could have a significant independent influence on yield.

The difference in yields from WS1 and WS3 compared with WS2 is also evident in terms of unit area yields (inches) (table 1) which are consistently and significantly $(\mathrm{P}<.05)$ less from both WS1 and WS3. This is a contradiction of the previously cited statement of theory that water yield per unit area increases with increasing watershed area. The WS1/WS3 comparison is borderline significance. $(.1<\mathrm{P}<.05)$.
Average stormflow peaks as well as annual yields rank in the same order as entire watershed (master order) areas, and also scale very nearly the same as annual yields (table 2). WS1 and WS3 peaks scale to WS2 in almost exactly the same ratio. Consequently the IVS1/WS3 scale ratio is almost exactly $1: 1$, and the scale ratios are different than for area.

The different area and yield scale ratios in both the WS1/WS2 and WS3/WS2 comparisons definitely suggest that other elements besides area also influence or at least partially control the volume yields and peak flows. On the other hand, the nearly $1: 1$ scale ratios in the WS1/ WS3 comparison still suggest primary area control. Now the main questions are "What elements, if any, scale more nearly the same as 
yield and peak flows than do areas in the WS1/ WS2 and WS3/WS2 comparisons?", and "Are ratios of other elements consistent with the similitude indicated by closeness of the area and yield scale ratios in WS1 versus WS3?" Similar questions are pertinent regarding constancy of nondimensional elements.

\section{Linear Aspects of Drainage Basin and Channel System}

Dimensional Elements. - In terms of linear elements listed in table 3, WS1 and WS3 scale about the same as they do in terms of area and yield, including order one average, order one total, and master order (total watershed) - with one outstanding exception: the trunk channel mesh length, master order. WS3, though smaller in area, is larger than WS1 in terms of master channel trunk length but smaller in terms of water yield.

Order one elements are included in the preceding section and in tables 2 and 3 because of evidence that the character of entire watersheds of hierarchy greater than order one is in real sense controlled by or is related to character of contained first order basins (Morisawa 1962). Except for master channel mesh length, the consistency of tabulated scale ratios in the WS1/WS3 comparison thus far supports this contention.

However, little consistency is apparent in either the WS1/WS2 or WS3/WS2 ratios, nor are both of any pair of ratios in table 3 consistent with yield ratios except for maximum basin length. On the other hand, the near 1:1 ratios of order one averages again indicate relatively close similarity of order one basins among watersheds. Hence, planimetric parameters of order one averages cannot possibly explain differences in yield scale. However, in terms of sum total area of order one, WS1 and WS3 are even larger in relation to WS2 than they are in terms of area of master order (table 2 ). This scale difference is also obvious in order one sum-total-area proportion of master order areas which are 55, 47, and 59 percent for WS1, WS2, and WS3, respectively. All other area (interbasin area) drains directly into second or higher order channels where conveyance loss very likely is less.

The almost exact correspondence of the scale ratios of maximum length of the master watersheds with yield and peak flow scale ratios is accepted as evidence that maximum length is a primary control element in both yield and peak flow. The other listed elements, including area, are seemingly less effective.

Dimensionless Elements.-The weighted mean bifurcation ratios of WS1, WS2, and WS3, respectively, are 3.43. 4.64, and 5.15. The value of 3.43 means that, on the average, there are 3.43 times more channels of any given order than of the next higher order. According to Strahler (1964) bifurcation ratios between 3 and 5 are characteristics of basins not having distorted geologic structure. The borderline value for WS3 suggests possible structural distortion which may account for certain scale distortions. The above values in general are similar to ones reported by Melton (1957) for basins of similar lithology in New Mexico, Arizona, Utah, and Colorado.

Table 3.--Average values (L) and scale ratios ( $\lambda$ ) of horizontal linear elements of drainage basins and their channel systems

\begin{tabular}{|c|c|c|c|c|c|c|c|c|}
\hline \multirow[b]{2}{*}{ rsheds } & \multicolumn{2}{|c|}{$\begin{array}{l}\text { Trunk channel } \\
\text { (mesh length) }\end{array}$} & \multicolumn{2}{|c|}{$\begin{array}{c}\text { Maximum basin } \\
\text { length (ML) }\end{array}$} & \multicolumn{2}{|c|}{$\begin{array}{c}\begin{array}{c}\text { Maximum basin } \\
\text { width } \\
\text { (MW) }\end{array} \\
\end{array}$} & \multicolumn{2}{|c|}{$\begin{array}{r}\text { Basin } \\
\text { perimeter }(\mathrm{P})\end{array}$} \\
\hline & $\begin{array}{c}\text { First order } \\
\text { average }\end{array}$ & $\begin{array}{r}\text { Master } \\
\text { order }\end{array}$ & $\begin{array}{c}\text { First order } \\
\text { average }\end{array}$ & $\begin{array}{r}\text { Master } \\
\text { order } \\
\end{array}$ & $\begin{array}{c}\text { First order } \\
\text { average }\end{array}$ & $\begin{array}{r}\text { Master } \\
\text { order }\end{array}$ & $\begin{array}{c}\text { First order } \\
\text { average }\end{array}$ & $\begin{array}{r}\text { Master } \\
\text { order } \\
\end{array}$ \\
\hline & ---- & - & _ & $--\mathrm{Fe}$ & ---- & --- & ----- & -- \\
\hline WSI & 574 & 4,926 & 625 & 4,665 & 276 & 2,775 & 1,486 & 13,740 \\
\hline & ---- & --- & ---- & Scale & ios $\lambda$ & - & ---- & -- \\
\hline WS 1/WS 2 & 1.19 & 1.43 & 0.98 & 1.31 & 0.94 & 1.80 & 0.97 & 1.56 \\
\hline WS $3 /$ WS 2 & 1.09 & 1.88 & .94 & 1.19 & .96 & 1.53 & .94 & 1.62 \\
\hline WS1/WS 3 & 1.10 & .76 & 1.04 & 1.10 & .98 & 1.17 & 1.02 & .96 \\
\hline
\end{tabular}


Generally speaking, axil angles, the upper angle of entry of a channel into a channel of next higher order, are similar in all three watersheds. For order one entry into order two, the average angles are 50, 52, and 52 degrees respectively for WS1, WS2, and WS3. These acute angles are to be expected, considering the relative steepness of the watersheds. Entry tends more toward right angles on gentler slopes and toward even more acute angles on steeper slopes.

Basin Azimuth. - The azimuth of basin diameter (downstream direction) for all orders, and associated average ground slopes were plotted on polar coordinate paper. These plottings showed that the majority of component basins in all three watersheds face north. WS3 has the most distinctive pattern of azimuth versus slope distribution. No basins face south to west, a concentration of the steeper slopes face east, and concentrations of the gentler slopes face northeast and northwest. WS2 has no basins facing southeast to west. WS1 has the most even distribution in full azimuth, but here too the heaviest concentration faces generally north.

\section{Area Aspects of Drainage Basins}

Dimensional Elements.-Gross areas and the area scale ratios have already been presented in table 2. Other well-known area aspects of drainage basins are drainage density (miles of channel per square mile of area, dimensionally equal to $\mathrm{L}^{-1}$ ), the constant of channel maintenance (square feet of watershed area per foot of channel length, dimensionally equal to
$\mathrm{L}$, and the inverse of drainage density), and channel segment frequency (number per square mile, dimensionally equal to $\mathrm{L}^{-2}$ ). Computed values and scale ratios are shown in table 4. Again the WS1/WS3 scale ratios are the most consistent with scale ratios already presented (yield, area, and linear dimensions), but still there is enough discrepancy to suggest distortion. WS1 has slightly less length of channel per unit of watershed area (or more area per unit of channel length) than WS3, and slightly less than indicated by area and yield scale ratios. Channel segment frequency is almost exactly the same on the two watersheds which also indicates distortion. WS1 would have to have fewer channel segments per unit area for the scale ratios to be consistent with those for area and yield, or conversely, WS3 would have to have a greater number of channel segments per unit of area.

It is again in the scale ratios involving comparison of WS2 with WS1 and WS3 that distortions from both volume yield and area ratios are most pronounced. The near 1:1 or smaller scale ratios in the WS1/WS2 comparison indicate that WS2 has about the same or just slightly fewer miles of channel per square mile of area than WS1 (drainage density), about the same or slightly more area per foot length of channel (constant of channel maintenance), and about the same to a slightly smaller number of channel segments per square mile of area (channel segment frequency). The same contrasts are present in comparing WS3 with WS2, except that they are even more pronounced. Thus, WS2 draining the smallest area has a less finely dissected drainage network than either of the larger watersheds.

Table 4.--Area elements of the watersheds and their scale ratios $(\lambda)$

\begin{tabular}{|c|c|c|c|c|c|c|}
\hline \multirow{2}{*}{ Watersheds } & \multicolumn{2}{|c|}{ Drainage density } & \multicolumn{2}{|c|}{$\begin{array}{l}\text { Constant of channe1 } \\
\text { maintenance }\end{array}$} & \multicolumn{2}{|c|}{$\begin{array}{l}\text { Channel segment } \\
\text { frequency }\end{array}$} \\
\hline & First order 1 & Master order & First order & Master order & First order & Master order \\
\hline & \multicolumn{2}{|c|}{$\mathrm{Mi} / \mathrm{sq} \mathrm{mi}$} & \multicolumn{2}{|c|}{ Sq $f t / f t$} & \multicolumn{2}{|c|}{ No/sq mi } \\
\hline WS1 & 13.21 & 13.41 & 400 & 394 & 225 & 174 \\
\hline WS 2 & 13.38 & 13.09 & 395 & 403 & 229 & 137 \\
\hline \multirow[t]{2}{*}{ WS 3} & 14.91 & 14.98 & 354 & 352 & 236 & 175 \\
\hline & --- & ---- & - - Scale & tios $\lambda$ - - & ---- & -- \\
\hline WS 1/WS 2 & 1.01 & 0.98 & 1.01 & 0.98 & 1.01 & 0.89 \\
\hline WS 3/WS 2 & .90 & .87 & .90 & .87 & .98 & .88 \\
\hline WS1/WS3 & 1.13 & 1.12 & 1.13 & 1.12 & 1.02 & 1.00 \\
\hline
\end{tabular}

${ }^{1}$ First order values computed from totals of first order areas and channel lengths rather than from averages. 
Dimensionless Elements (Shape).-Several of the most commonly used shape elements are presented in table 5. The "lemniscate" is perhaps the most realistic because its somewhat "pear" or "teardrop" shape more frequently approximates real watershed shapes than other measures such as the circle (Chorley et al. 1957). However, some common attributes are apparent.

The length and area of a watershed are combined to calculate the "lemniscate constant" which defines basic length/width proportions of a perfect lemniscate having the same area and same length as the watershed (see section on Definitions and Derivations).

The larger the constant the more elongate the outline. A value of unity indicates a circle. The lemniscate ratio then indicates how closely the actual watershed shape approaches the perfect lemniscate. A ratio of unity would indicate perfect correspondence.

As shown in table 5 , the order one constants indicate relatively elongated lemniscates, and the ratios indicate relatively close approach to the perfect lemniscate shape in all three watersheds. In master order (entire watersheds), the constants indicate a more rotund shape for WS1 and WS3 but still a fairly elongate shape for WS2. The WS2 lemniscate ratio indicates closest correspondence with the perfect shape. More discrepancy is present in the other watersheds - particularly WS3. Shape distortion of WS3 is clearly visible in figure 2.

A general consistency of individual order one shape elements among watersheds further strengthens the evidence of their similarity.

The most outstanding and consistent feature of master watersheds is the greater relative elongation of WS2 than the other watersheds. The marked exceptions involve WS3, which most poorly fits the lemniscate shape as indicated by the constants. WS3 is also least circular and most elongate when master channel mesh length is used in place of maximum basin length. The shape elements also support the possibility of geologic distortion of WS3 (perhaps through difference in jointing of igneous mass) as interpreted from the higher bifurcation ratios pointed out previously.

\section{Relief Aspects of Drainage Basins}

Relief is of fundamental importance because of its critical role in watershed dynamics particularly in velocity and the resulting eroding power of flowing water. The concept of relief is easily visualized and understood, but measurement and expression of the relief of complex watershed forms in terms that can be related to hydraulic or hydrologic performance is problematical. Depending on intended use, relief is expressed either in terms of absolute vertical rise (dimensionally equal to $\mathrm{L}$ ) or vertical rise per unit of some horizontal length dimension (a dimensionless ratio).

Dimensional.-Relief of geometrically similar watersheds should be in the same proportions as horizontal linear elements. Relief can be expressed in many ways, ranging from maximum basin relief to rise along the trunk channel from the watershed mouth to the watershed divide. The latter property may not be appropriate for oddly shaped basins or basins with the highest point at some place other than the point farthest removed along the

Table 5.--Dimensionless area elements (shape) of the study watersheds

\begin{tabular}{|c|c|c|c|c|c|c|}
\hline \multirow{2}{*}{ Dimensionless area elements } & \multicolumn{2}{|c|}{ Watershed 1} & \multicolumn{2}{|c|}{ Watershed 2} & \multicolumn{2}{|c|}{ Watershed 3} \\
\hline & $\begin{array}{l}\text { First } \\
\text { order }\end{array}$ & $\begin{array}{l}\text { Master } \\
\text { order }\end{array}$ & $\begin{array}{l}\text { First } \\
\text { order }\end{array}$ & $\begin{array}{l}\text { Master } \\
\text { order }\end{array}$ & $\begin{array}{l}\text { First } \\
\text { order }\end{array}$ & $\begin{array}{l}\text { Master } \\
\text { order }\end{array}$ \\
\hline Leminscate constant & 2.48 & 1.81 & 2.63 & ${ }^{1} 2.57$ & 2.39 & 1.70 \\
\hline Leminscate ratio & .97 & .85 & .95 & .93 & .96 & ${ }^{2} .75$ \\
\hline Elongation ratio, using average-- & & & & & & \\
\hline Circularity ratio & .70 & .63 & .65 & .63 & .70 & 4.51 \\
\hline $\begin{array}{l}\text { Maximum length/maximum width, using } \\
\text { averages }\end{array}$ & 2.26 & 1.68 & 2.17 & ${ }^{1} 2.31$ & 2.12 & 1.78 \\
\hline averages & .32 & .43 & .30 & 1.31 & .33 & .46 \\
\hline
\end{tabular}

\footnotetext{
${ }^{1}$ Most elongate, master order.

2 Poorest fit, master order.

${ }^{3}$ Least elongate, first order.

${ }^{4}$ Least circular, master order.
} 
Table 6.--Dimensional aspects of basin relief

\begin{tabular}{|c|c|c|c|c|c|c|}
\hline \multirow[b]{2}{*}{ Watersheds } & \multicolumn{2}{|c|}{$\begin{array}{l}\text { Rise along trunk channel } \\
\text { (mesh length) }\end{array}$} & \multicolumn{2}{|c|}{$\begin{array}{c}\text { Rise along maximum basin } \\
\text { length (ML) }\end{array}$} & \multicolumn{2}{|c|}{$\begin{array}{c}\text { Rise from lowest point on } \\
\text { basin perimeter (maximum } \\
\text { basin relief, } \mathrm{H} \text { ) }\end{array}$} \\
\hline & $\begin{array}{c}\text { First order } \\
\text { average }\end{array}$ & $\begin{array}{r}\text { Master } \\
\text { order }\end{array}$ & $\begin{array}{l}\text { First order } \\
\text { average }\end{array}$ & $\begin{array}{l}\text { Master } \\
\text { order }\end{array}$ & $\begin{array}{c}\text { First order } \\
\text { average }\end{array}$ & $\begin{array}{r}\text { Master } \\
\text { order }\end{array}$ \\
\hline & ---- & --- & ---- & --- & ----- & -- \\
\hline WS1 & 189 & 535 & 207 & 539 & 217 & 710 \\
\hline WS2 & 145 & 521 & 174 & 573 & 180 & 580 \\
\hline \multirow[t]{2}{*}{ WS 3} & 165 & 555 & 191 & 508 & 200 & 623 \\
\hline & ---- & -- & - - - Scale & os $\lambda-$ & ----- & --- \\
\hline WS1/WS2 & 1.30 & 1.03 & 1.19 & 0.94 & 1.20 & 1.22 \\
\hline WS $3 /$ WS 2 & 1.14 & 1.07 & 1.10 & .89 & 1.11 & 1.07 \\
\hline WS $1 /$ WS 3 & 1.14 & .96 & 1.08 & 1.06 & 1.08 & 1.14 \\
\hline
\end{tabular}

drainage line from the mouth. Values and scale ratios of three measures of relief in the Sturgis watershed are presented in table 6 .

The foregoing general consistency of WS1/ WS3 linear scale is preserved in both first order averages and in master order. However, increasing distortions are evident in the WS1/ WS2 and WS3/WS2 comparisons. For example, the ratios of order one averages in all classes of elements thus far considered have indicated relatively close similarity of order one basins among the three watersheds. Now, in the case of relief, there is strong suggestion of scale ratios consistently greater than unity. In fact, the ratios approach the yield scale ratios. Conversely, the master order scale ratios are nearer unity.
Dimensionless.-Three primary relief properties are measured in dimensionless terms channels, valley side slopes, and interrelations of these two which reduce basically to areamean-slopes. Typical values are presented in table 7 .

First order channels average a slightly gentler gradient in WS2 than in WS1 or WS3; WS3 is second, and WS1 first order gradients are steepest. Average ground slopes of first order basins occur in the same sequence and have practically the same values. Slope ratio, which combines these two factors, indicates slightly steeper average channel gradient than ground slope in WS2. The difference probably is not significant, however, and the ratio is probably not significantly different from those

Table 7.--Dimensionless relief properties of the Sturgis watershed

\begin{tabular}{|c|c|c|c|c|c|c|}
\hline \multirow[b]{2}{*}{ Dimensionless relief properties } & \multicolumn{2}{|c|}{ Watershed 1} & \multicolumn{2}{|c|}{ Watershed 2} & \multicolumn{2}{|c|}{ Watershed 3} \\
\hline & $\begin{array}{l}\text { First } \\
\text { order }\end{array}$ & $\begin{array}{l}\text { Master } \\
\text { order }\end{array}$ & $\begin{array}{l}\text { First } \\
\text { order }\end{array}$ & $\begin{array}{l}\text { Master } \\
\text { order }\end{array}$ & $\begin{array}{l}\text { First } \\
\text { order }\end{array}$ & $\begin{array}{l}\text { Master } \\
\text { order }\end{array}$ \\
\hline Trunk channel gradient mesh length (percent) & 32.9 & 10.9 & 30.0 & 15.2 & 31.5 & 8.6 \\
\hline Basin maximum length relief ratio & .33 & .12 & .27 & .16 & .32 & .12 \\
\hline Relative relief (basin ML relief $\div$ perimeter) & .14 & .039 & .11 & .065 & .13 & .036 \\
\hline Valley side slope (percent) & 42.2 & 53.2 & 40.6 & 50.1 & 38.9 & 42.7 \\
\hline Average ground slope (percent) & 33.6 & 37.8 & $29 \cdot 3$ & 36.4 & 31.7 & $34 \cdot 3$ \\
\hline $\begin{array}{c}\text { Slope ratio (channel gradient, mesh } \\
\text { length } \div \text { average ground slope) }\end{array}$ & .98 & .29 & 1.02 & .42 & .99 & .25 \\
\hline Ruggedness number (DD $x$ MH $\div 5280)$ & .62 & 1.80 & .49 & 1.44 & .68 & 1.78 \\
\hline
\end{tabular}


for WS1 or WS3, which are practically identical in the first order.

An opposite trend is apparent in master order trunk channel gradient (mesh length). WS2 is the steepest, which is reflected in the slope ratio. Values of master order slope ratios are also lower than those of first order. This means that master channels become less steep downstream, while average ground slope actually increases. Relative change is less in WS2 than in WS1 or WS3. Hence, the slope ratio is highest in WS2. "Ruggedness numbers" indicate a similar trend. Where there is the greatest contrast between channel gradient and mean ground slope (lowest slope ratio) ruggedness number is highest. Thus, WS1 and WS3 are "more rugged" than WS2. It so happens that, since drainage densities remain nearly the same with increasing order, ruggedness is in the same order as maximum relief, and indicates increasing slope steepness downstream in all three watersheds. Similar relationships are evident in valley side slope. WS1 is steepest, WS2 intermediate, and WS3 the gentlest sloping in both first and master order. In all three cases, side slopes become steeper downstream (master order). Contrast is least in WS3.

In summary, WS2, which yields the most water per unit area and which yields proportionately more than might be expected from area scale ratios, has:

1. More gently sloping order one channels (mesh length).

2. Gentlest average ground slope in order one.

3. Steepest master channel (mesh length).

4. Largest slope ratio (least difference between average ground slope and master channel gradient) consequently is least rugged both in first order and master order.

WS1, on the other hand, has:

1. Steepest first order channels.

2. Steepest valley side slopes, both first order and master order.

3. Slightly steepest average ground slope, both first order and master order.

\section{WS3 has:}

1. Gentlest master channel slopes.

2. Gentlest valley side slopes, both first order and master order.

3. Lowest average ground slope of master watershed.

Slope distributions (from hypsometric analyses) lead to similar conclusions. These analyses indicated, for example, that 47,36 , and 20 percent of the areas of WS1, WS2, and WS3, respectively, have slopes steeper than 40 percent. The differences here are of greater relative magnitude than differences in average grourid slope of the master watersheds, though in the same sequence.

\section{Hypsometric Function}

Percentage hypsometric curves, which are graphs of the continuous function relating relative height to relative area of the entire watersheds, are shown in figure 3 . The first order-master order percentage integrals for WS1, WS2, and WS3, respectively, are: 53.8$55.5 ; 57.0-54.3$; and 53.9-55.7. These values indicate almost identical percentages of the reference volumes of the total basins remaining. Hence, it may be concluded that the overall erosion and degradation process has been closely similar on all three watersheds.

Despite the close similarity indicated by the integrals, there are differences in distribution. The curves in figure 3 indicate, for example, that WS1 has approximately 72 percent of its horizontal area above median elevation, compared with 60 and 57 percent for WS2 and WS3. This is in line with the higher percentage of slopes steeper than 40 percent in WS1 than in WS2 and WS3, the steeper average ground slope of WS1, and the increasing ruggedness downstream.

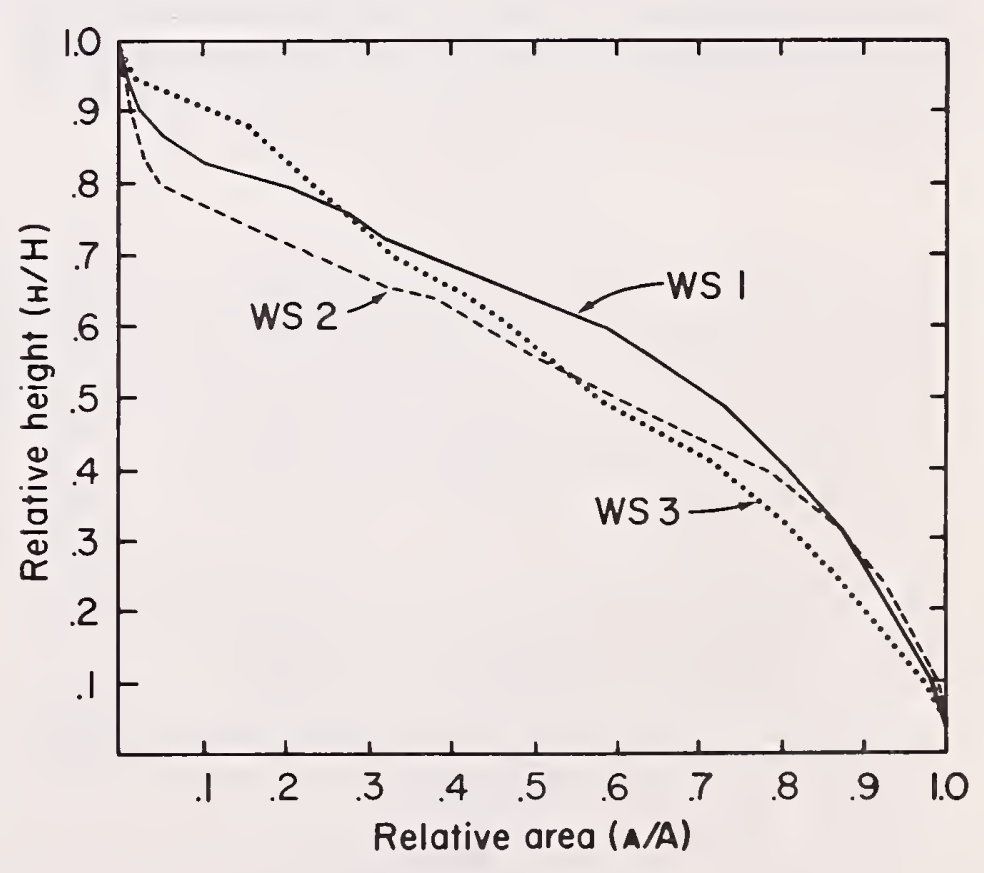

Figure 3. - Percentage hypsometric curves (areaelevation distribution), Sturgis watersheds. 


\section{Longitudinal Profiles of Principal Channel}

If the hypsometric integrals and curves are accepted as indices of steady-state drainage basins, then the longitudinal channel profiles represent graded streams or profiles of equilibrium. The graded stream has been taken to mean that the stream has just that slope which provides the competency and capacity to transport its load. In these adjoining basins where relief is similar, WS2 with its shortest stream length (horizontal map projection) has the steepest stream gradient. The weighted stream gradients (Taylor and Schwarz 1952) as shown in figure 4 indicate relatively straight profiles. Generally a graded stream is said to have a smooth, concave longitudinal profile, but concavity alone is not a reliable index to equilibrium. The straight profiles reflect relatively uniform rock control and minor deposition along the channels. Downcutting is negligible in these drainages, and lateral expansion is dominant.

\section{Discussion-Summary}

This paper reports detailed form (morphometric) comparisons of three small, contiguous watersheds. All three are on one of the granitelike early Tertiary intrusions that dot the northern Black IIills. Ponderosa pine forest dominates the entire area. Specification of morphometric elements is based on principles set forth by Horton (1945) and elaborated by Strahler $(1958,1964)$ and his associates. The watersheds are assumed to be in "steady state" (input-output equilibrium) which is quasi-timeindependent (Strahler 1964). The study watersheds and their component subbasins of all orders are also assumed to be an "ensemble" whose variation in space is a reflection of possible variation in time on a single watershed (Scheidegger and Langbein 1966). This is the rationale upon which the detailed comparisons of the watersheds are based.

In a macroscopic sense, it must be concluded that the watersheds are alike since they are contiguous, are oriented about the same, all have the same type of bedrock, and all are subject to the same climatic environment. In the absence of further detail, it would be appropriate to consider water yield, for example, only in terms of averages for the ensemble. But where other theoretically relevant details such as morphometric variations are available or are derived, it is postulated that they can be related to variations in hydrologic response within the ensemble.

The three study watersheds differ in gross area, gross water yield, and peak stormflows. Applying concepts of dimensional analysis and geometric similitude, and calculating scale ratios, it is obvious that the watersheds are also geometrically dissimilar. Greatest scale dissimilarity (or distortion) is evident in comparison of the two largest with the smallest watershed.

It is postulated that dimensional elements having scale ratios most nearly the same as water yield are best related to or control yield, despite extreme distortion in other respects.

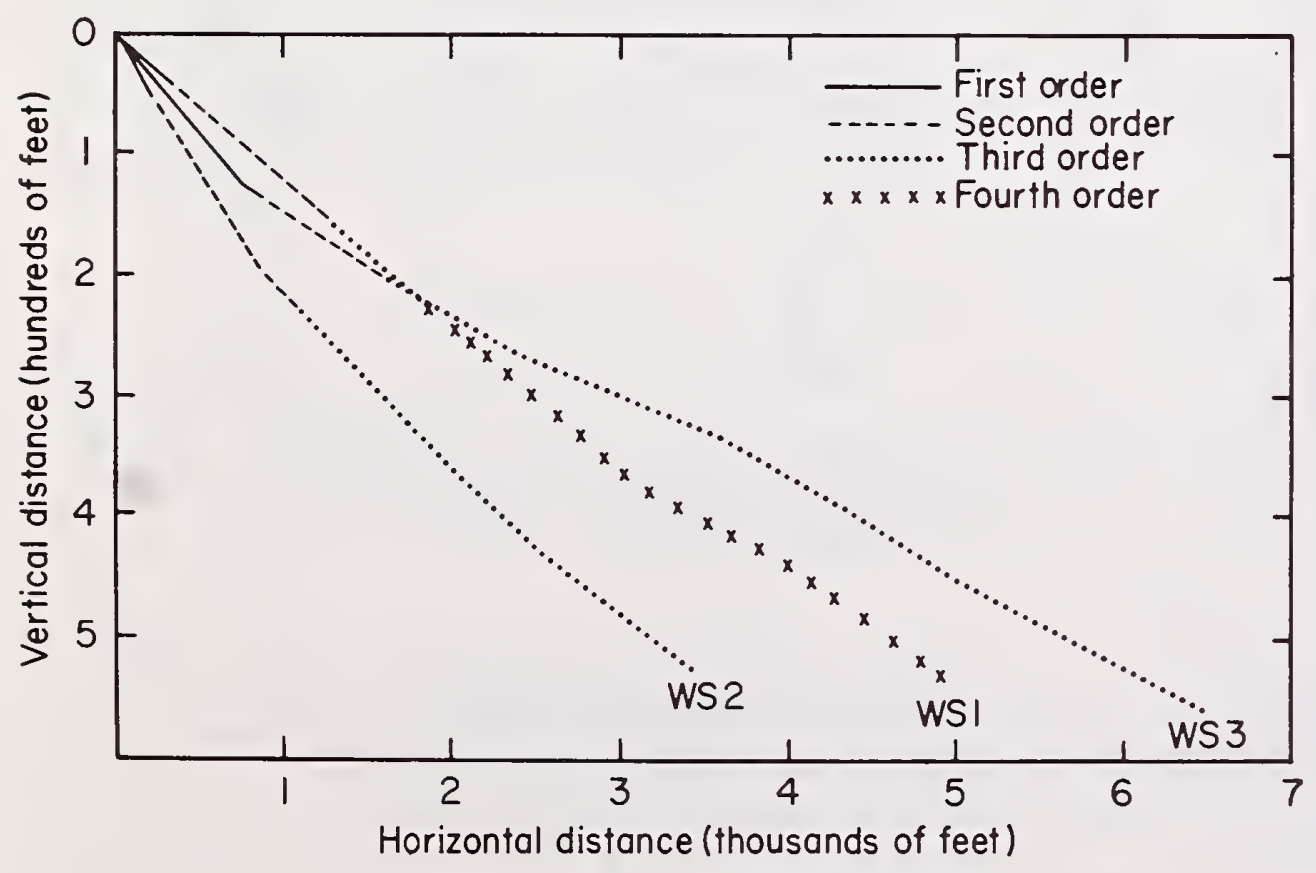

Figure 4. -

Longitudinal profiles of the master channels of the

Sturgis watersheds. 
The "most probable" relationships based on this postulate can be seen in the graphical summary of scale ratios in figure 5 .

In the WS1/WS2 comparison, two elements scale almost exactly the same as yield - maximum length of the master basin and average relief of first order channels (mesh length). The same two elements also scale most nearly the same as yields and peaks in the WS3/WS2 comparison. Other elements that scale closely enough with yield and peak flows in both comparisons to suggest some possible but lesser degree of control include average mesh length of first order channels, total rise along maximum length of first order basins, and maximum relief of both first order and master basins.

In the WS1/WS3 comparisons, the same elements scale with yield and peak flows as in the WS1/WS2 and WS3/WS2 comparisons plus practically all of the other dimensional elements except for master channel mesh length. In this respect WS3 scales substantially larger than WS1. WS3 also scales slightly larger than WS1 in terms of perimeter of master order basin and master channel relief (mesh length), but the distortion is less obvious. The similarity of first order average area and horizontal linear characteristics among watersheds is ap- parent in the clustering of scale ratios close to the $1: 1$ (1.0) level in all three comparisons. However, there is a definite departure from 1:1 scale in first order relief elements, which suggests at least partial control of yield and peak flow.

Average shapes of first order basins are also similar among all three master watersheds. Moderate to close similarity is indicated in all of the seven computed indices. However, there is a definite difference among the master watersheds. WS2 with its more regular outline is the most elongate, relatively, but IVS3 shape is definitely distorted. This was suggested in the greater master channel mesh length and perimeter in WS3 than in WS1, and is confirmed in the shape indices. There is nothing particularly distinctive about shape in WS1 except that there is an apparent tendency for first order basins, as is also the case in both WS2 and WS3, to be more elongate than the master order.

Dimensional elements of maximum length of master basin and average rise from channel mouth to basin divide of first order basins exert the greatest apparent control over yield and peaks. The combination of length and rise expresses slope gradient as a dimensionless
AnNual hater yield ( $Y$ )

PEAK FLOW (P)

AREA

Channel mesh Length

MAXIMUM BASIN LENGTH

MAXIMUM BASIN WIDTH

BASIN PERIMETER

DRAinAge DeNSITY

Channel frequency

Trunk CHANNel RISE (MESH)

RISE ALONG MAXIMUM BASIN LENGTH

MaXimUM basin ReLief

$A=$ FIRST ORDER AVERAGE,

$M=$ MASTER ORDER .

I = TOTAL INTERBASIN AREA,
WS I/WS2

wS 3 /WS2

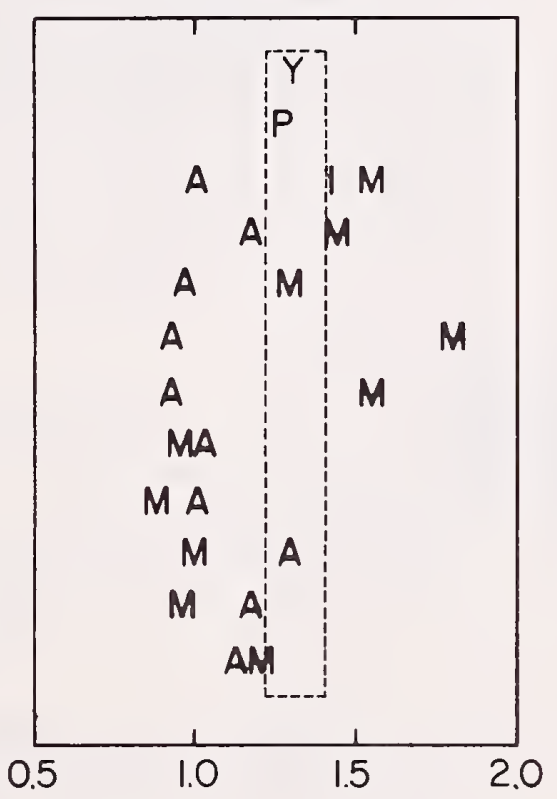

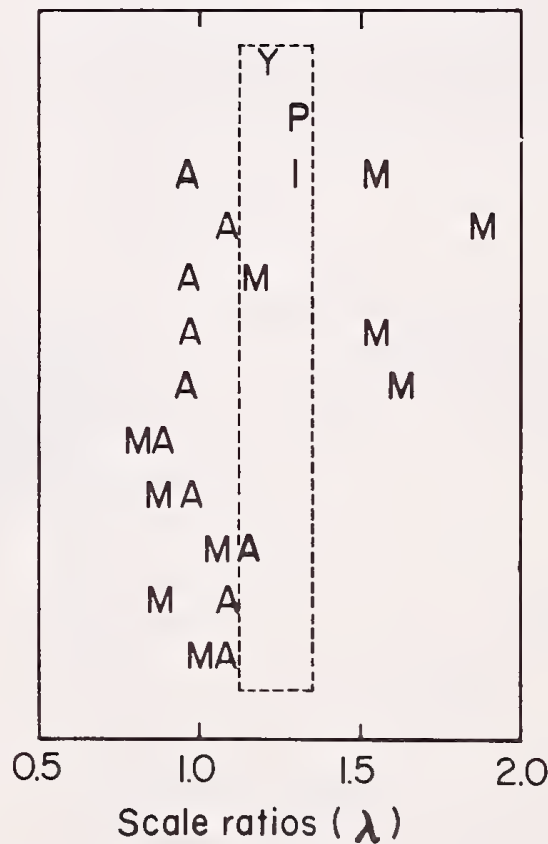

WSI/WS3

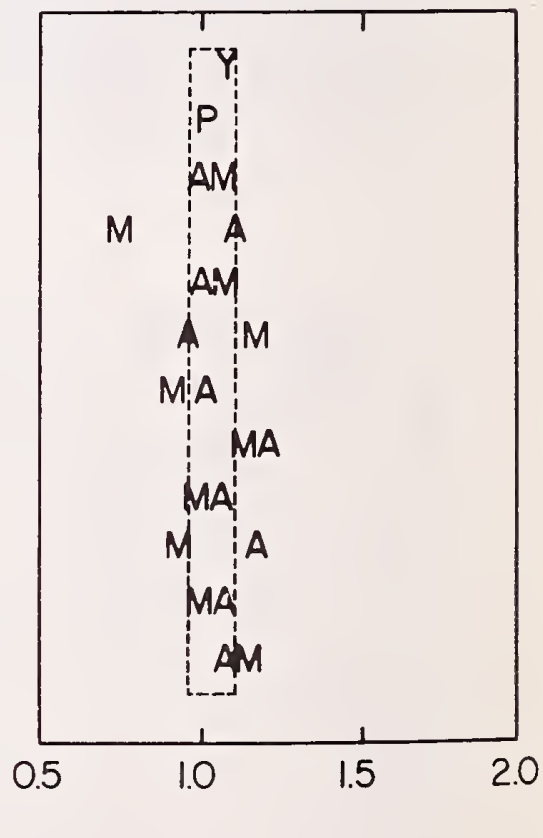

Figure 5. - Scale ratios of linear dimensions of the Sturgis watersheds. It is postulated that those elements most nearly in vertical alinement with $Y$ and $P$ (yield and peak flow scale ratios)are most closely associated with and hence are primary controls of $Y$ and $P$. 
number. Computed values indicate WS2 has the most gently sloping first order channels but the steepest main channel. WS1, on the other hand, has the steepest valley side slopes in both first order and master order, and also the steepest average ground slope in both first order and master order. WS3 has the most gently sloping master channel, valley side slopes (both first and master order), and average ground slope (master order). The contrasts in relief are further emphasized in slope distribution analysis, which indicates that 47,36 , and 20 percent, respectively, of the total areas of WS1, WS2, and WS3 have slopes steeper than 40 percent.

Indications are that, within the restricted scope of this study - on one rock type, and under spatially uniform climate - maximum length of master watershed and relief of the contained first order basins are more meaningful indicators of relative vield and stormflow peaks than is gross area. WS2, the smallest area of the three, is relatively the most elongate and has the most gently sloping first order channels linked to the steepest master channel. WS2 also has the smallest percentage of total area in the first order basins, which means that a larger percentage of total area (interbasin) drains directly into second or higher order channels, on or near bedrock, where channel transmission loss should be minimum. This may be one of the important reasons why WS2 has a higher relative yield than either WS1 or WS3.

This study has produced some insights regarding the relative importance of a variety of morphometric elements to volume of water yield and storm peak discharges. Interpretations need to be further tested by extension to other watersheds of the same geologic type and on to other geologic types. Concurrent studies are needed on the influences and interactions of other factors, especially soil and rock mantle characteristics and their distribution.

\section{Literature Cited}

Chorley, Richard E., D.E.G. Malm, and

II.A. Pogorzelski.

1957. A new standard for estimating drainage basin shape. Amer. .I. Sci. 255: $13 \mathrm{r}-141$.

Hack, .T. T.

1960. Interpretation of erosional topography in humid temperate regions. Amer. J. Sci. 25\$A: 80-97.
Horton, Robert T.

1945. Erosional development of streams and their drainage basins; hydrophysical approach to quantitative morphology. Geol. Soc. A mer. Bull. 96: 275-370.

Maxwell, .J. C.

1960. Quantitative geomorphology of the San Dimas Experimental Forest, California. Columbia Univ. Dep. Geol., ONR, Geogr. Branch, N.Y., Tech. Rep. 19, Proj. NR 389-042, 95 p.

Melton, Mark A.

1957. An analysis of the relations among elements of climate, surface properties, land geomorphology. Columbia L'niv. Dep. Geol., ONR, Geogr. Branch, N.Y., Tech. Rep. 11, Proj. NR 389-042, 102 p.

Morisawa, Marie E.

1962. Quantitative geomorphology of some watersheds in the Appalachian Plateau. Geol. Soc. Amer. Bull. 73: 1025-1046.

Ogrosky, Harold O., and Victor Mockus.

1964. Hydrology of agricultural lands. Sect. 21, p. 21-1 to 21-97. In Handbook of applied hydrology, edited by Ven Te Chow. N. Y.: McGraw-Hill Book Co.

Radeke, R. E., and Fred C. Westin.

1963. Gray wooded soils of the Black Hills of South Dakota. Soil Sci. Soc. Amer. Proc. 27: 573-576.

Scheidegger, A. E., and W. B. Langbein.

1966. Probability concepts in geomorphology. U.S. Geol. Survey Prof. Pap. 500-C, $14 \mathrm{p}$.

Strahler, Arthur $\mathrm{N}$.

1952. Hypsometric (area-altitude) analysis of erosional topography. Geol. Soc. Amer. Bull. 63:1117-1142.

1958. Dimensional analysis applied to fluvially eroded landforms. Geol. Soc. Amer. Bull. 69: 279-300.

1964. Geology. Quantitative geomorphology of drainage basins and channel networks. Sect 4-II, p. 4-39 to 4-76. In Handbook of applied hydrology, edited by Ven Te Chow. N.Y.: McGraw-Itill Book Co.

Taylor, A. B., and II. E. Schwarz.

1952. Unit-hydrograph and peak flow related to basin characteristics. Amer. Geophys. Union Trans. 33: 235-246. 
Stream or channel: (used interchangeably) drainageway.

Stream order: Level of succession in joining of tributaries within a drainage network. Strahler's (1952) method designates the smallest unbranched tributaries as first order. Confluence of two streams of the same order forms a stream of next higher order.

Trunk stream: Extension of channel of any order in an upstream direction through the hierarchy to and including first order. Extension is based on rules established by Horton (1945) as follows: (a) starting below any junction, a straight line is extended upstream through the bifurcation; (b) the stream joining at the lesser angle is designated the trunk stream; (c) if junction angles are about the same, the longer stream is taken as the trunk stream or trunk channel.

Stream segment: Any complete single stretch of stream or channel of any given order. A first order stream or channel segment terminates where an incised channel is no longer visible.

Mesh length: Straight line extension of stream length to the basin divide (dimension L).

Master watershed: Entire watershed (complete hierarchy).

Master channel: Trunk channel of the master watershed.

Maximum basin length (ML): Horizontal straight-line distance from watershed mouth to most distant point on the watershed divide (dimension $\mathrm{L}$ ).

Maximum basin width (MW): Maximum width normal to ML (dimension L).

Basin diameter: Horizontal straight-line distance from basin mouth approximately parallel (in line) with master channel to watershed divide. Criteria given by Maxwell (1960) aid in reproducibility (dimension L).

Basin perimeter: Horizontal distance around the periphery (dimension L).

Bifurcation ratio: Ratio of the number (N) of basins of order $u$ to number of streams of next higher order (dimensionless).

Basin azimuth: Degrees of arc in a horizontal angle measured clockwise from true north to the mouth direction of the basin diameter (dimensionless).

Axil angle: Term denoting angle of lunction of tributaries or entrance angle. It is the upper angle between the main channel and a branch (dimensionless).
Basin area: Acres of square miles, horizontal projection (dimension $\mathrm{L}^{2}$ ).

Drainage density: Total length (miles) of all streams of all orders in a watershed per unit of horizontal area (square mile) (dimension $\mathrm{L}^{-1}$ ).

Constant of channel maintenance: Horizontal area, square feet, per foot length of channel (inverse of drainage density) (dimension L).

Stream frequency: Number of stream segments per square mile of watershed area (dimension $\mathrm{L}^{-2}$ ).

Circularity ratio: Ratio of the area of a basin to the area of a circle having the same perimeter as the basin. The closer the ratio approaches unity the more circular the shape (dimensionless).

Elongation ratio: Ratio of the diameter of a circle having the same area as the basin to basin diameter. The smaller the ratio the more elongate the shape (dimensionless).

ML/MW: Ratio of maximum basin length to maximum basin width (dimensionless).

A/ML ${ }^{2}$ : Ratio of basin area to the square of maximum basin length (dimensionless).

Lemniscate constant $(\mathrm{k}): \mathrm{k}=1^{2} \mathrm{II} / 4 \mathrm{~A}$ where 1 is the maximum basin length (ML) and $\mathrm{A}$ is basin area. The constant $\mathrm{k}$ expresses the relationship between the maximum length and maximum width of the loop of a lemniscate, as illustrated below. (After Chorley et al. 1957).

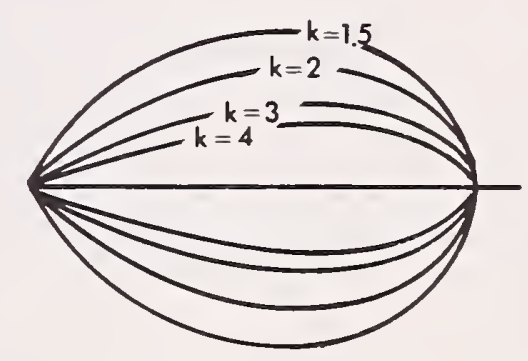

The loop is circular when the constant is unity (dimensionless).

Lemniscate ratio: Ratio of the perimeter of the lemniscate shape indicated by $k$ to the actual drainage basin perimeter. The closer the lemniscate ratio approaches unity the nearer the basin shape approaches that of the pure lemniscate (dimensionless).

Rise or relief (used interchangeably): Increase in elevation, usually in feet (dimension L).

Maximum basin relief: Rise from lowest to highest point on the basin perimeter (dimension L). 
Slope or gradient: Rise per unit of horizontal distance, a ratio, usually expressed in percent (dimensionless).

Basin ML relief ratio: Ratio of rise along ML to ML (dimensionaless).

Relative relief: Ratio of rise along ML to basin perimeter. Perimeter as the denominator permits characterization of oddly shaped basins where highest relief is located away from the point opposite the basin mouth (dimensionless).

Valley side slope: Gradient of valley sides leading directly to stream channels, measured normal to contour (dimensionless).

Average ground slope: Total length of contours multiplied by contour interval and divided by basin area (dimensionless).

Slope ratio: Ratio of channel gradient (mesh length) to average ground slope (dimension- less). It is a measure of the horizontal angle that the lateral slope makes relative to the channel slope. A low slope ratio indicates that the lateral inflow tends to enter the streams at right angles, whereas the angle of inflow becomes more acute as channel slope approaches ground slope. The slope ratio tends to decrease with increase in drainage area.

Ruggedness number: Drainage density multiplied by maximum basin relief and divided by 5,280 (after Strahler 1958). The larger the number the more rugged.

Percentage hypsometric curve: The plot of a continuous function relating relative height to relative area.

Hypsometric integral: The relative area below the hypsometric curve (dimensionless). 


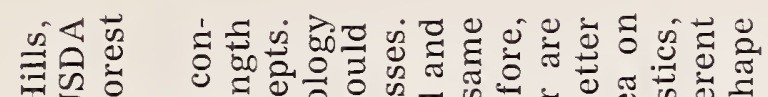

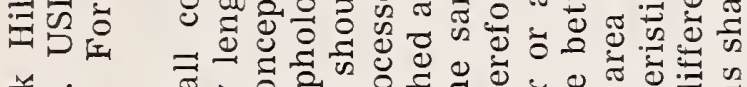

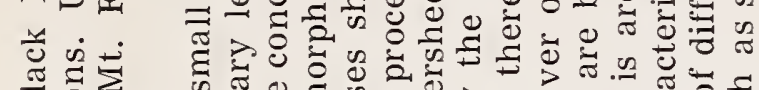

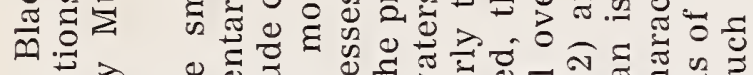

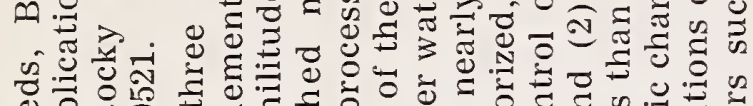

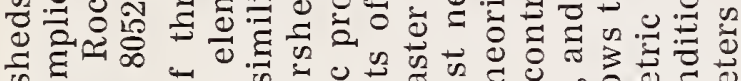

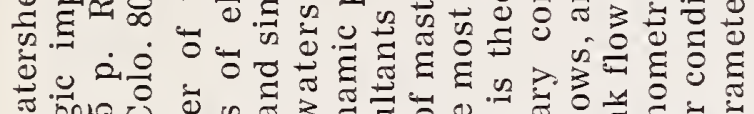

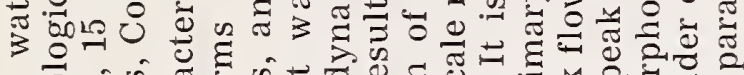

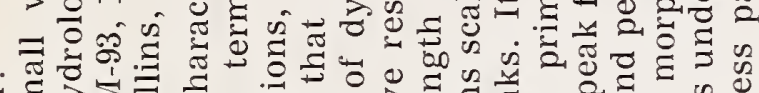

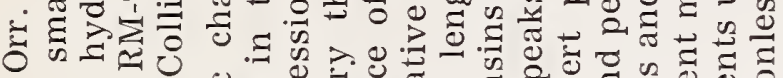

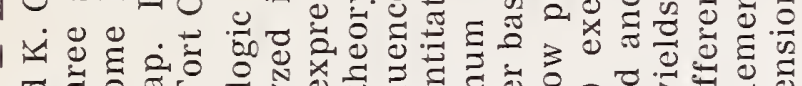

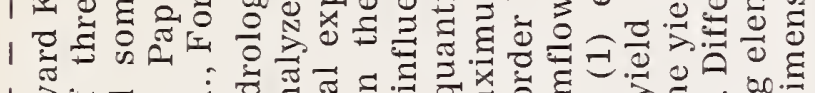

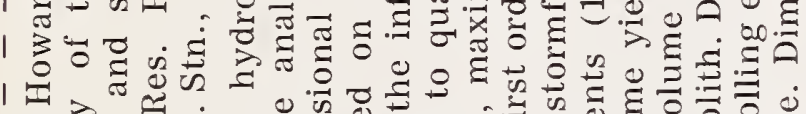

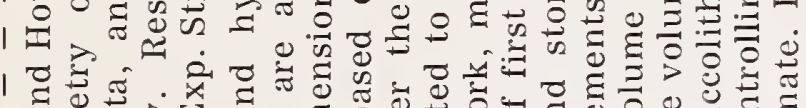
(1)

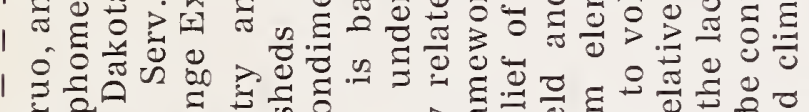

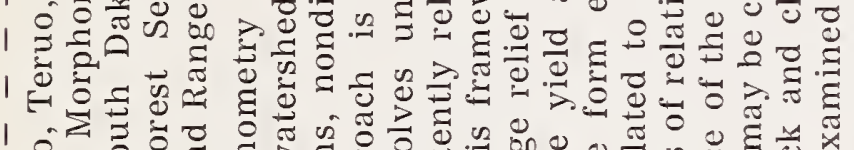

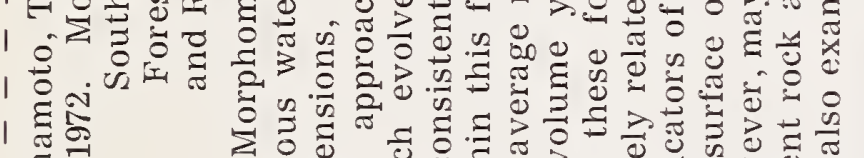

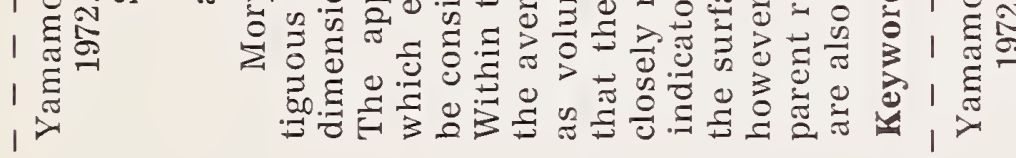

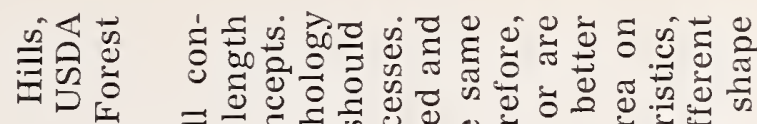

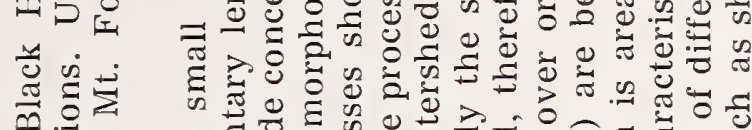

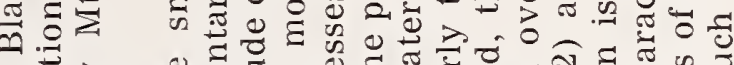
s.

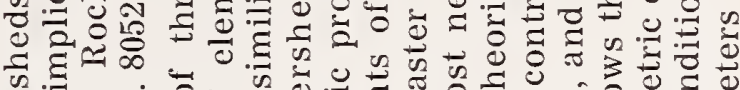
- 1 क

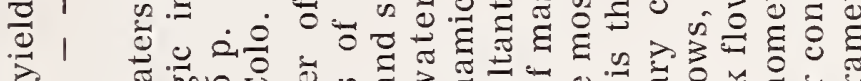
1 10 席 150

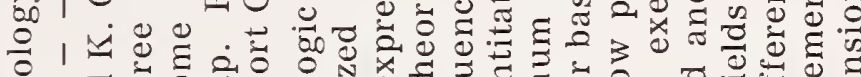

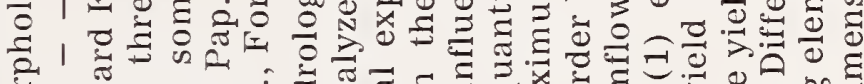

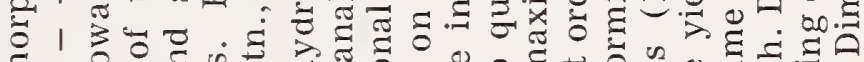

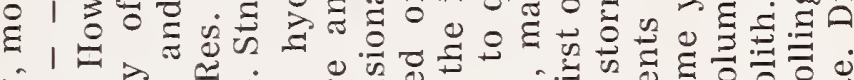

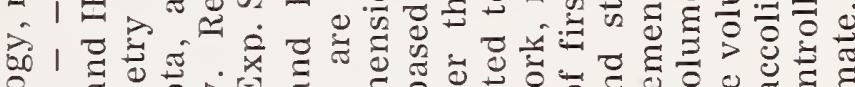
응 1 \% 跣 1)

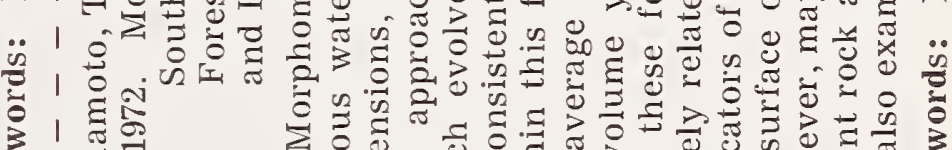

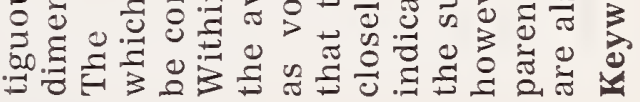

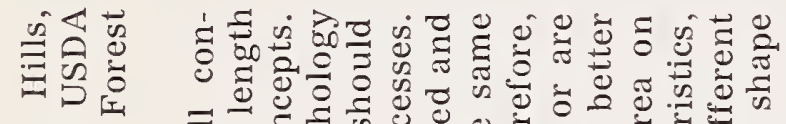

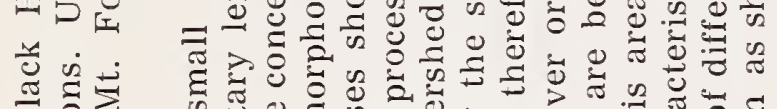

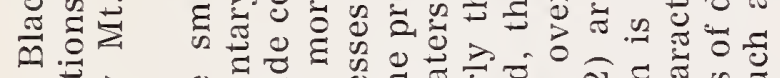

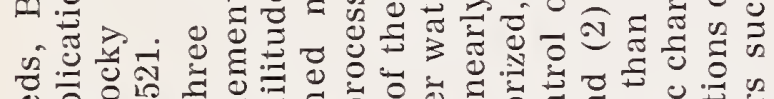

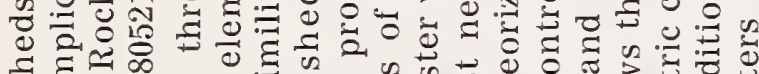

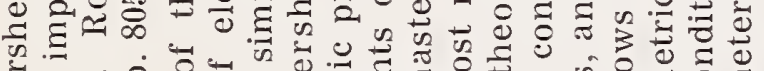
क人

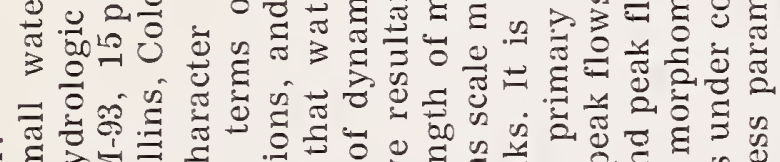

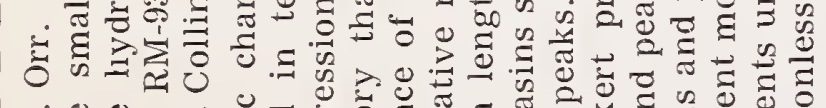

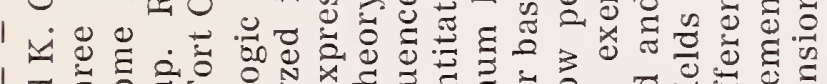

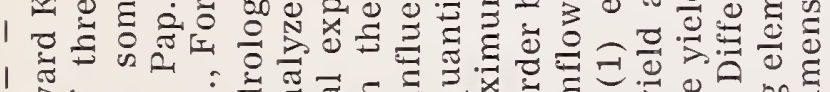

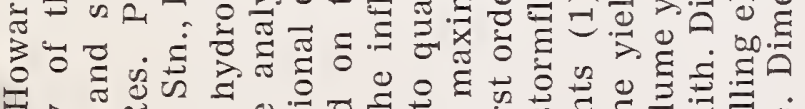

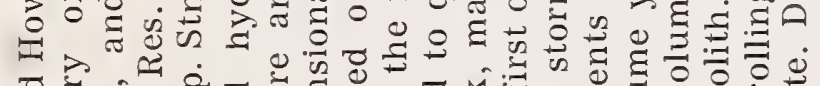

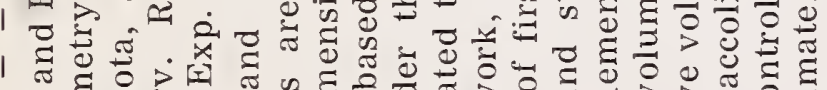

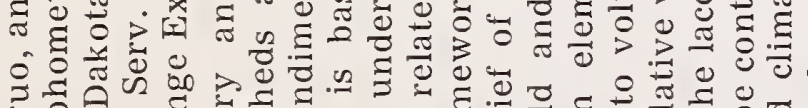

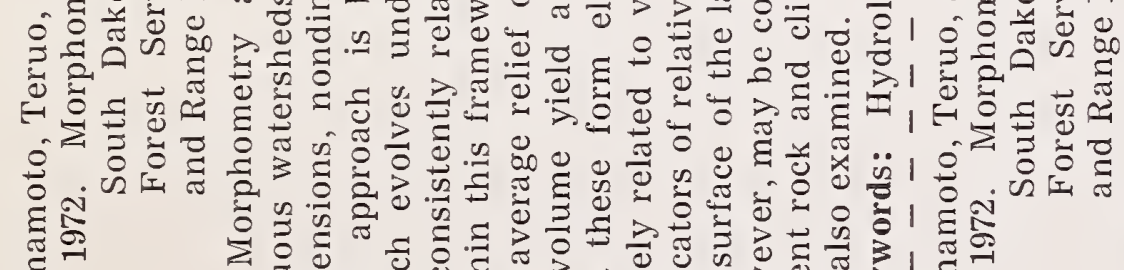

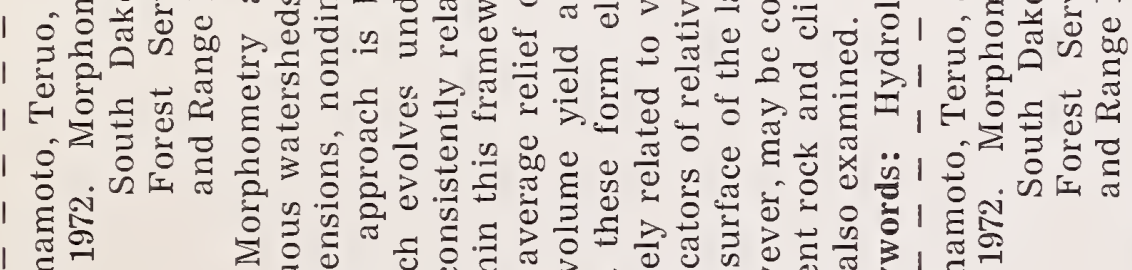
, 1

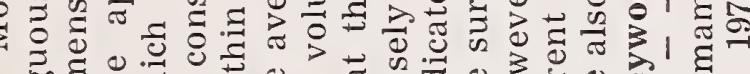

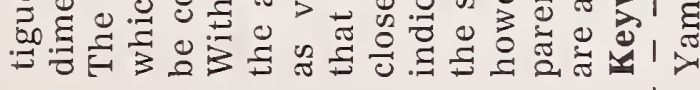

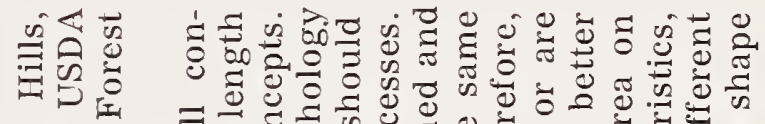

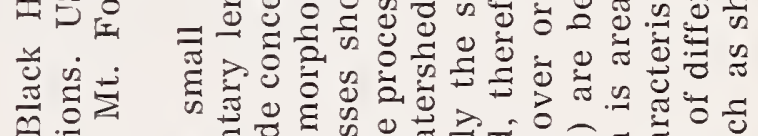

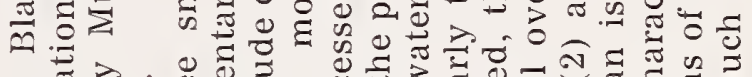
v.

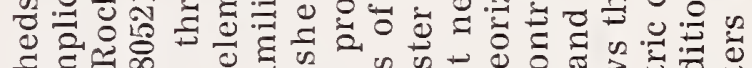
기 क्ष

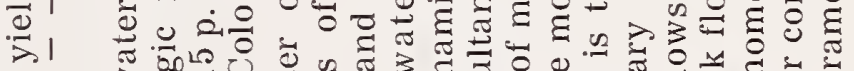
(1)

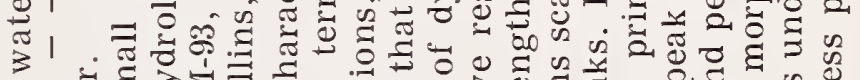
11

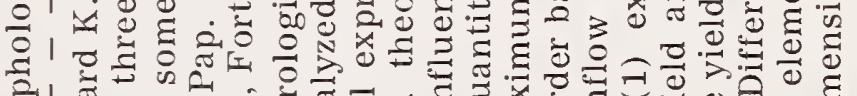

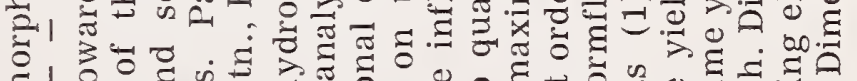

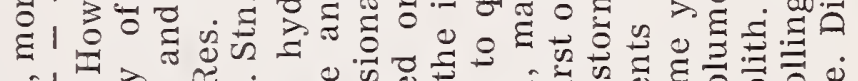

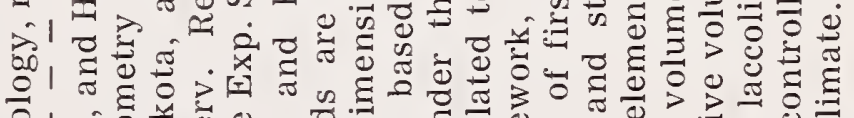
0
0
0
0
0
0
0
0
0
0
0
0
0
0
0
0
0

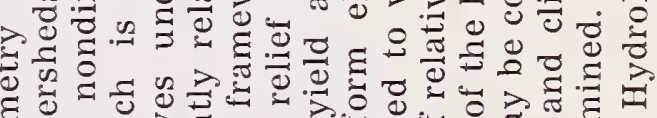

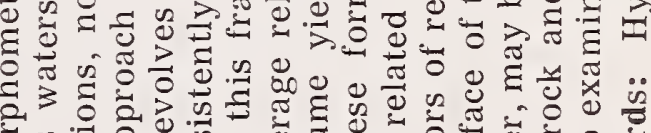

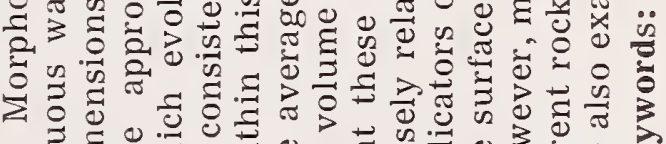

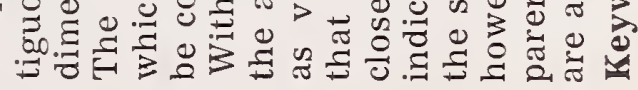




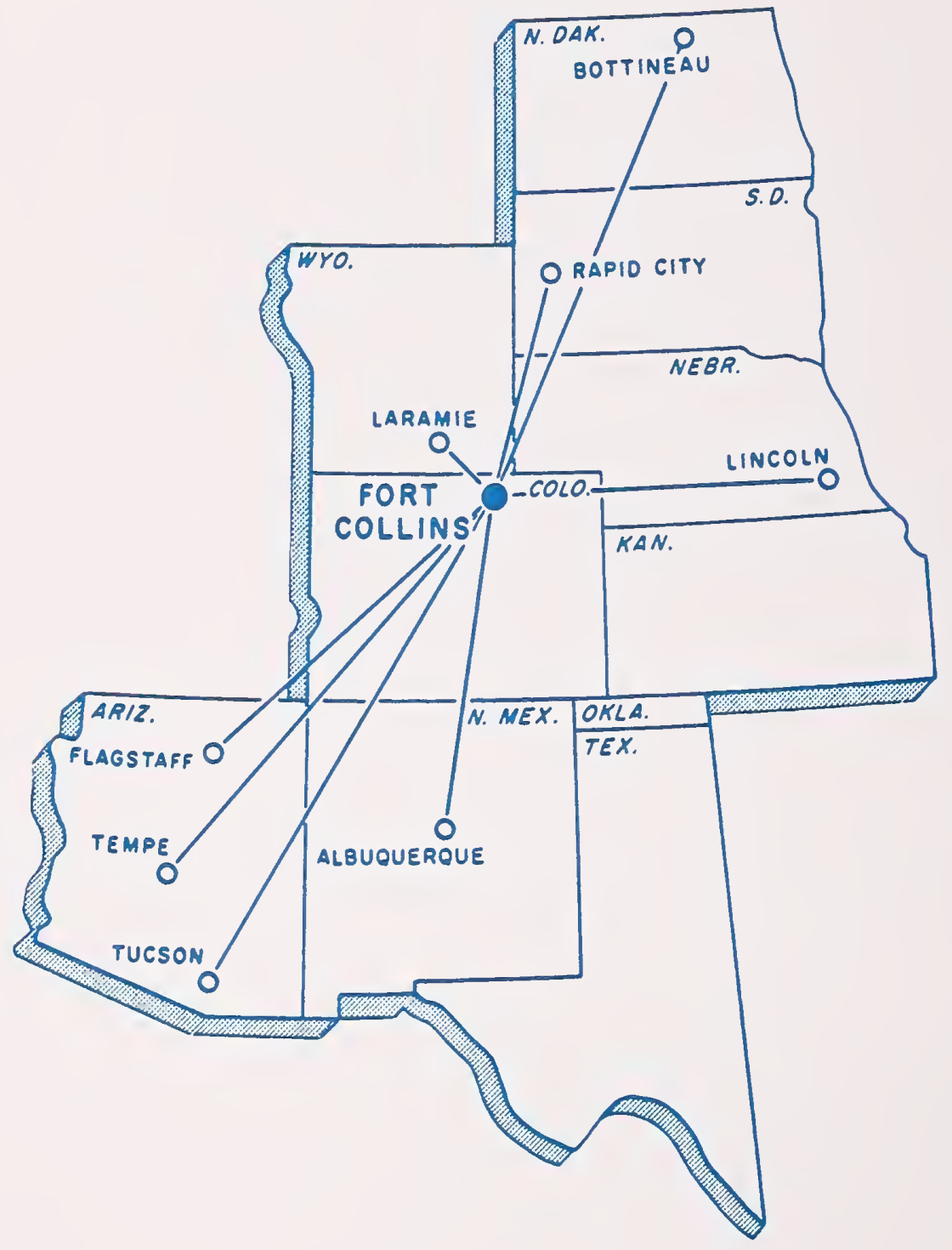

